\title{
THE DEVELOPMENT OF 990 GOLD - TITANIUM: ITS PRODUCTION, USE AND PROPERTIES
}

\author{
Geoffrey Gafner*
}

\begin{abstract}
Pure gold with only one per cent of titanium may well be the only significantly different new jewellery and coinage alloy developed in recent times. In this paper, an account is given of the development of a 990 fineness gold alloy with good colour, durability and mechanical properties, and why titanium was chosen as the alloying metal. Methods are described for the alloy's production, solutionizing and age-hardening. Mechanical properties are given as a function of deformation, age-hardening time and temperature for three different starting states. These properties are compared with those of some standard 14 and 18 carat jewellery alloys and pure gold.
\end{abstract}

\section{Introduction}

Statistics indicate that over 40 per cent of the value of jewellery sold in the world's major markets is derived from the sale of pieces costing US $\$ 500$ or more. The top segment of the market is thus strong and a demand is likely to exist for very high caratage jewellery as long as it is acceptably durable.

Research with a view to developing new materials, which would allow the manufacture of such jewellery, had been an objective of the International Gold Corporation Ltd. (Intergold) since 1974, when a study of composites of gold with up to one per cent of various oxides was carried out in association with Engelhard Industries as an extension of earlier studies made by this corporation [1] and by others [2-4]. The composites were made by conventional powder metallurgy techniques and a number of their relevant physical properties were recorded [5].

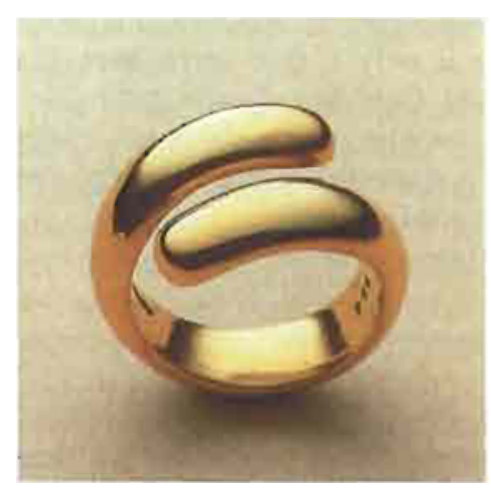

Wrought ring in 990 gold, by Marcia Lorberfeld
The expected strengthening of the metal was observed both at normal and higher temperatures but the products were not deemed attractive for general use in jewellery fabrication. This work was not taken further until after 1980 when studies were carried out by staff of Degussa's Wolfgang Research Laboratories near Frankfurt, with Intergold and Degussa sharing costs.

In the first of these studies gold was alloyed with small amounts of reactive metals, such as zirconium, and in situ reaction thereof with gases such as oxygen and nitrogen attempted at high temperature and pressure [6]. Due to the extremely low permeability of gold to such gases, little reaction (and thus hardening) occurred at meaningful depths and the approach was dropped.

* Dr Geoffrey Gafner was Research Manager with International Gold Corporation when the work reported here was carried out. $\mathrm{He}$ is now in retirement, but may be contacted c/o Editor, Gold Bulletin. 
In the second study, gold and selected glass powders were combined using the methods of powder metallurgy to give a range of new gold-glass composites [7,8]. These proved well-suited to stamping but involved too high a level of technology for general use by goldsmiths. Doubts also existed about purchaser acceptance of this strange combination of materials.

There the matter rested until Intergold's Hong Kong branch requested in 1983 [9] that an attempt be made to improve the durability of the gold used to make the traditional Chuk Kam jewellery of that region, for which purpose some 20 tons of gold are currently consumed annually. By law, this jewellery has to have a millesimal fineness of at least 990 .

For the first time thus, an objective was defined--develop a gold-based material with at least 990 fineness, with colour close to that of pure gold and with durability (resistance to wear and impact) as good as that of standard jewellery alloys.

This objective has been achieved through the development of a gold-titanium alloy with 990 millesimal fineness $(23.75 \mathrm{ct})$. Details of the development of this 990 alloy are presented here with some of its properties.

\section{Determination of best probable hardening additive}

A generally held assumption at the time was that it would be impossible to harden gold effectively by alloying it with only one weight per cent or less of another metal. It was decided to test this assumption, and a thorough study of the recently reassessed gold binary phase diagrams [10] by Okamoto and Massalski was made with a view to identifying additives which could be used to precipitation-harden gold. For this to be possible, at least one weight percent of the alloying metal must dissolve readily in molten gold and stay in solution down to about $800^{\circ} \mathrm{C}$ (this is an ideal solutionizing temperature) in order to allow the alloy to be produced in a ductile form by quenching from this temperature. Between this temperature and about $400^{\circ} \mathrm{C}$, the additive should segregate to form a hardening phase with as large a volume as possible.

In order to develop an index of probable hardening effectiveness, Table I was drawn up (p. 114).

The eleven candidate binary alloys are listed with the solubilities of the second components in gold at 800 and $400^{\circ} \mathrm{C}$. The column headed $H_{w}$ indicates the fraction of one weight per cent which would precipitate on extended heating at $400^{\circ} \mathrm{C}$. The column headed ' $\mathrm{A}$ ' gives the atomic weight ratios of gold to the alloying metal and $H_{A}\left(=H_{W} A\right)$ expresses the amount of additive in the hardening phase in atomic percent. Multiplying this by the number of atoms in the hardening phase gives a measure of the relative volumes of the hardening phases formed $\left(\mathrm{NH}_{\mathrm{A}}\right)$. This is related to the probable hardening effectiveness of the additive but, as other factors are also involved, it does no more than indicate where to start experimentation.

It will be noted that titanium has by far the highest hardening factor and that the metals with the highest factors are all extremely reactive. That the use of vacuum techniques would be required was thus inescapably indicated at this point.

\section{Commissioning of research}

The Forschungsinstitut für Edelmetalle und Metallchemie (FEM) in Schwäbisch Gmünd, Federal Republic of Germany, was commissioned to carry out research into the hardening of gold by one weight percent of titanium in 1984, and this proved successful immediately with ready attainment of acceptable hardness, colour and durability [11]. In what follows, results will be presented which were obtained at the FEM and certain other organizations which became involved in the research or trials relating to ' 990 ' gold, as the alloy has come to be known.

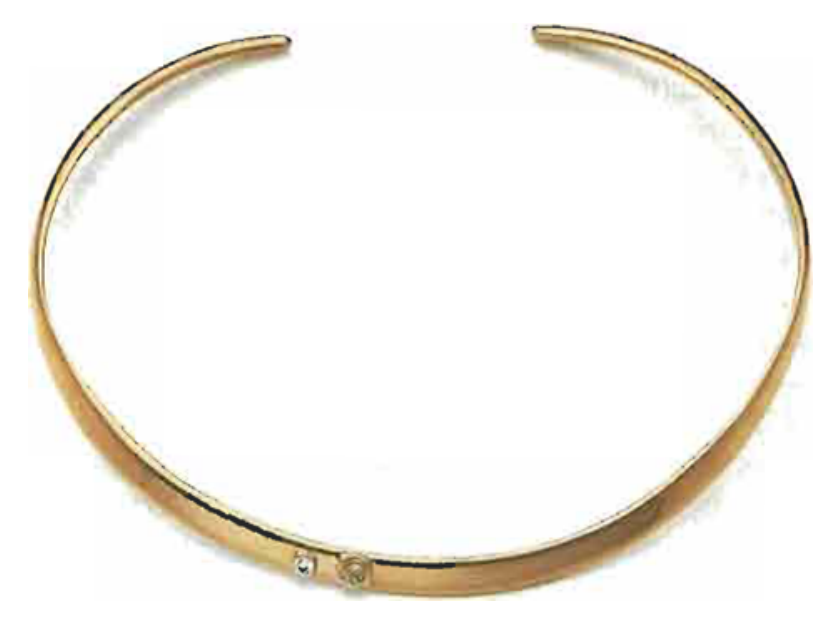

Bracelet in wrought 990 gold by Marcia Lorberfeld 


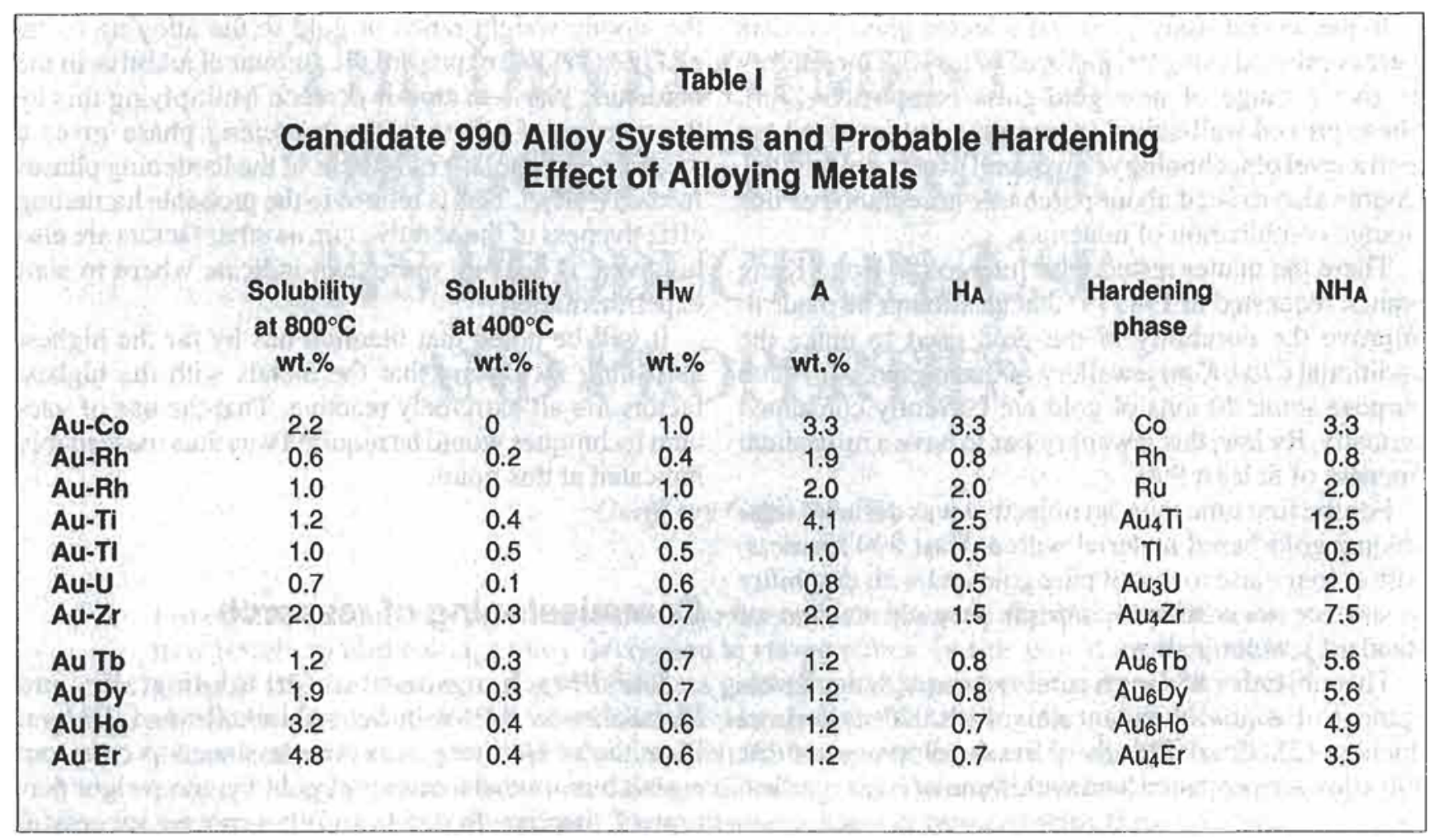

\section{Alloy production}

The alloy can be produced as follows: the desired quantity of 999.9 fineness gold is loaded into an alumina or zirconia crucible in a vacuum induction furnace.

The vacuum chamber is evacuated and heated at $800^{\circ} \mathrm{C}$ until degassing is complete and then backfilled with high-purity argon to a pressure of at least 1 torr.

The gold is melted and heated to $1300^{\circ} \mathrm{C}$ and a titanium block (or rods) with a mass of 1/99 of that of the gold, and purity of at least 99.7 per cent, dropped into the melt. A flash of light, the reason for which is not understood, accompanies the dissolution process. Titanium powder or thin wire should not be used as the tenacious surface oxide/nitride layer makes them hard to dissolve.

The molten alloy is then cast into a graphite or ceramic mould in the chamber and the casting cooled before air is introduced into the chamber.

This procedure is usually trouble-free and good mixing occurs. When small quantities of alloy (less than one kilogram) are produced, excessive agitation of the melt is caused by induction heating and some splashed metal hardens on the wall of the crucible. It is believed that this problem could be avoided by resistance heating of the crucible - a side effect might be poor mixing, however.

\section{Removal of tarnish layer}

Tarnish can be effectively removed [12] by dipping the casting into a 10 per cent solution of potassium pyrosulphate $\left(\mathrm{K}_{2} \mathrm{~S}_{2} \mathrm{O}_{7}\right)$ in water, drying in an oven or over a flame and then heating until the $\mathrm{K}_{2} \mathrm{~S}_{2} \mathrm{O}_{7}$ powder melts. A tarnish-free alloy is obtained after quenching and washing off the residue in water.

\section{Solutionizing (homogenizing) cast alloy}

Following scalping of the cast alloy or removing the tarnish layer as described above, it can be solutionized by holding at $800^{\circ} \mathrm{C}$ in vacuum for one hour and then cooling down as rapidly as possible in argon.

Surprisingly, tests have shown that no significant loss of titanium occurs when solutionizing is in air as a protective surface layer forms. This is brown, however, and must be subsequently removed by $\mathrm{K}_{2} \mathrm{~S}_{2} \mathrm{O}_{7}$ treatment as described earlier or by sandpapering. This treatment is not recommended.

Should the grain size of the alloy be important, the above should be preceded by 50 per cent work hardening. Not only does this give grain refinement but it also allows greater hardness to be attained in subsequent age-hardening steps at lower temperatures.

Work reported later in this paper indicates that solutionizing can also be carried out without tamishing in molten boric oxide or Degussa Salt 540. 


\section{Table II}

Colours, Compositions and Mechanical Properties of Selected Gold Alloys

( $S=$ soft, $\mathrm{C}=$ cold worked, $\mathrm{H}=$ hardened)

\begin{tabular}{|c|c|c|c|c|c|c|c|c|c|c|c|c|c|c|c|}
\hline \multirow[t]{2}{*}{ Colour } & \multicolumn{3}{|c|}{ Composition \%。 } & \multicolumn{3}{|c|}{ Hardness HV1 } & \multicolumn{3}{|c|}{$\begin{array}{l}0.2 \text { Yield } \\
\text { Strength MPa }\end{array}$} & \multicolumn{3}{|c|}{$\begin{array}{l}\text { Tensile Strength } \\
\text { MPa }\end{array}$} & \multicolumn{3}{|c|}{$\begin{array}{l}\text { Ductility } \\
\% \text { Elongation }\end{array}$} \\
\hline & $\mathrm{Au}$ & $\mathrm{Ti}$ & $\mathrm{Cu}$ & $\mathbf{s}$ & c & H & $\mathbf{s}$ & c & H & $\mathbf{s}$ & C & H & $\mathbf{s}$ & C & H \\
\hline $\begin{array}{l}\text { Yellows } \\
\text { Yellowc } \\
\text { Yellow }\end{array}$ & $\begin{array}{l}990 \\
990 \\
990\end{array}$ & $\begin{array}{l}10 \\
10 \\
10\end{array}$ & & 70 & $\begin{array}{l}120 \\
125 \\
175\end{array}$ & $\begin{array}{l}170 \\
210 \\
240\end{array}$ & 90 & $\begin{array}{l}300 \\
460\end{array}$ & $\begin{array}{l}360 \\
500 \\
660\end{array}$ & 280 & $\begin{array}{l}340 \\
520\end{array}$ & $\begin{array}{l}500 \\
550 \\
740\end{array}$ & 40 & $\begin{array}{r}2-8 \\
20\end{array}$ & $\begin{array}{l}20 \\
2-8 \\
13\end{array}$ \\
\hline & $\mathrm{Au}$ & Ag & $\mathrm{Cu}$ & & & & & & & & & & & & \\
\hline $\begin{array}{l}\text { Dark Yellow } \\
\text { Dark Yellow }\end{array}$ & $\begin{array}{l}917 \\
999.9\end{array}$ & 32 & 51 & $\begin{array}{l}70 \\
40\end{array}$ & $\begin{array}{l}165 \\
110\end{array}$ & : & 95. & 450 & - & $\begin{array}{l}275 \\
190\end{array}$ & $\begin{array}{l}500 \\
380\end{array}$ & $\therefore$ & $\begin{array}{l}30 \\
40\end{array}$ & $\begin{array}{l}1.0 \\
1.0\end{array}$ & : \\
\hline $\begin{array}{l}\text { Yellow } \\
\text { Pale Yellow } \\
\text { Yellow } \\
\text { Red }\end{array}$ & $\begin{array}{l}585 \\
585 \\
585 \\
585\end{array}$ & $\begin{array}{r}300 \\
265 \\
205 \\
90\end{array}$ & $\begin{array}{l}115 \\
150 \\
210 \\
325\end{array}$ & $\begin{array}{l}150 \\
175 \\
190 \\
160\end{array}$ & $\begin{array}{l}252 \\
250 \\
260 \\
270\end{array}$ & $\begin{array}{l}247 \\
260 \\
270 \\
260\end{array}$ & $\begin{array}{l}410 \\
430 \\
500 \\
350\end{array}$ & $\begin{array}{l}907 \\
850 \\
900 \\
800\end{array}$ & $\begin{array}{l}731 \\
730 \\
750 \\
600\end{array}$ & $\begin{array}{r}590 \\
550 \\
580 \\
1600\end{array}$ & $\begin{array}{r}932 \\
950 \\
1000 \\
2700\end{array}$ & $\begin{array}{l}767 \\
800 \\
800 \\
2600\end{array}$ & $\begin{array}{l}17 \\
30 \\
25 \\
45\end{array}$ & $\begin{array}{l}0 \\
1.0 \\
1.5 \\
1.5\end{array}$ & $\begin{array}{r}1 \\
3 \\
3 \\
12\end{array}$ \\
\hline $\begin{array}{l}\text { Pale Yellow } \\
\text { Yellow } \\
\text { Pink } \\
\text { Red }\end{array}$ & $\begin{array}{l}750 \\
750 \\
750 \\
750\end{array}$ & $\begin{array}{r}160 \\
125 \\
90 \\
45\end{array}$ & $\begin{array}{r}90 \\
125 \\
160 \\
205\end{array}$ & $\begin{array}{l}140 \\
150 \\
155 \\
165\end{array}$ & $\begin{array}{l}210 \\
230 \\
260 \\
240\end{array}$ & $\begin{array}{l}170 \\
230 \\
290 \\
330\end{array}$ & $\begin{array}{l}250 \\
300 \\
320 \\
300\end{array}$ & $\begin{array}{l}700 \\
750 \\
800 \\
800\end{array}$ & $\begin{array}{l}400 \\
600 \\
780 \\
850\end{array}$ & $\begin{array}{l}300 \\
520 \\
550 \\
550\end{array}$ & $\begin{array}{l}720 \\
900 \\
920 \\
950\end{array}$ & $\begin{array}{l}350 \\
750 \\
850 \\
950\end{array}$ & $\begin{array}{l}35 \\
40 \\
40 \\
40\end{array}$ & $\begin{array}{l}1.5 \\
3.0 \\
2.5 \\
2.0\end{array}$ & $\begin{array}{r}35 \\
15 \\
7 \\
4\end{array}$ \\
\hline
\end{tabular}

\section{Age-hardening of solutionized alloy}

The age-hardening characteristics of the alloy were established as follows: alloy was cast, homogenized at $800^{\circ} \mathrm{C}$ and quenched. Hardness was then determined as a function of time at appropriate temperatures [13]. Results are given in Figure 1. It will be noted that the hardest material $(180 \mathrm{HV})$ is obtained after 100 hours at $400^{\circ} \mathrm{C}$. This is too long to be applicable in practice. A hardness of $170 \mathrm{HV}$ is obtained after one hour at $500^{\circ} \mathrm{C}$. This is the recommended hardening procedure. A significantly lower hardness of $150 \mathrm{HV}$ is obtained after some thirty minutes at $600^{\circ} \mathrm{C}$.

\section{Work hardening of the alloy}

Figure 2 shows the effect of cold working on the alloy's hardness. Curve $S$ indicates that hardening occurs from a value of $75 \mathrm{HV}$ in the solutionized state to $125 \mathrm{HV}$ following 80 per cent cold working. Material which has been age-hardened to $125 \mathrm{HV}$ hardens further to $180 \mathrm{HV}$ with 80 per cent cold working (curve $\mathrm{H}$ ).

For purposes of comparison the cold-work/hardness curve (marked $18 \mathrm{ct}$.) is included for a typical 18 carat $3 \mathrm{~N}$ alloy with composition Au-Ag 125-Cu 125 [17]. This is clearly much harder in its softest state and work hardens rapidly. This necessitates intermediate anneal- ing steps when it is used for wrought jewellery production; 990 gold does not require such annealing.

\section{Mechanical properties of the alloy, in three different starting states, as a function of time at $500^{\circ} \mathrm{C}$}

If the alloy is to be of general use in jewellery manufacture, it must be available in soft and hard forms for wrought- and turned-jewellery production respectively. The properties of the alloy in three starting states were therefore studied to establish the best route to optimum material [14]. In all cases cast alloy was deformed by 23 per cent and solutionized by heating at $800^{\circ} \mathrm{C}$ for one hour followed by quenching. This was followed by a repetition of the same process to give soft starting material (S), by 23 per cent cold working to give cold worked material (C), and by age-hardening for 1 hour at $500^{\circ} \mathrm{C}$ and then cold working by 23 per cent to give the hardest material $(\mathrm{H})$.

Figure 3 shows the dependence of tensile and yield strengths of alloy in these three starting states on time of hardening at $500^{\circ} \mathrm{C}$. 

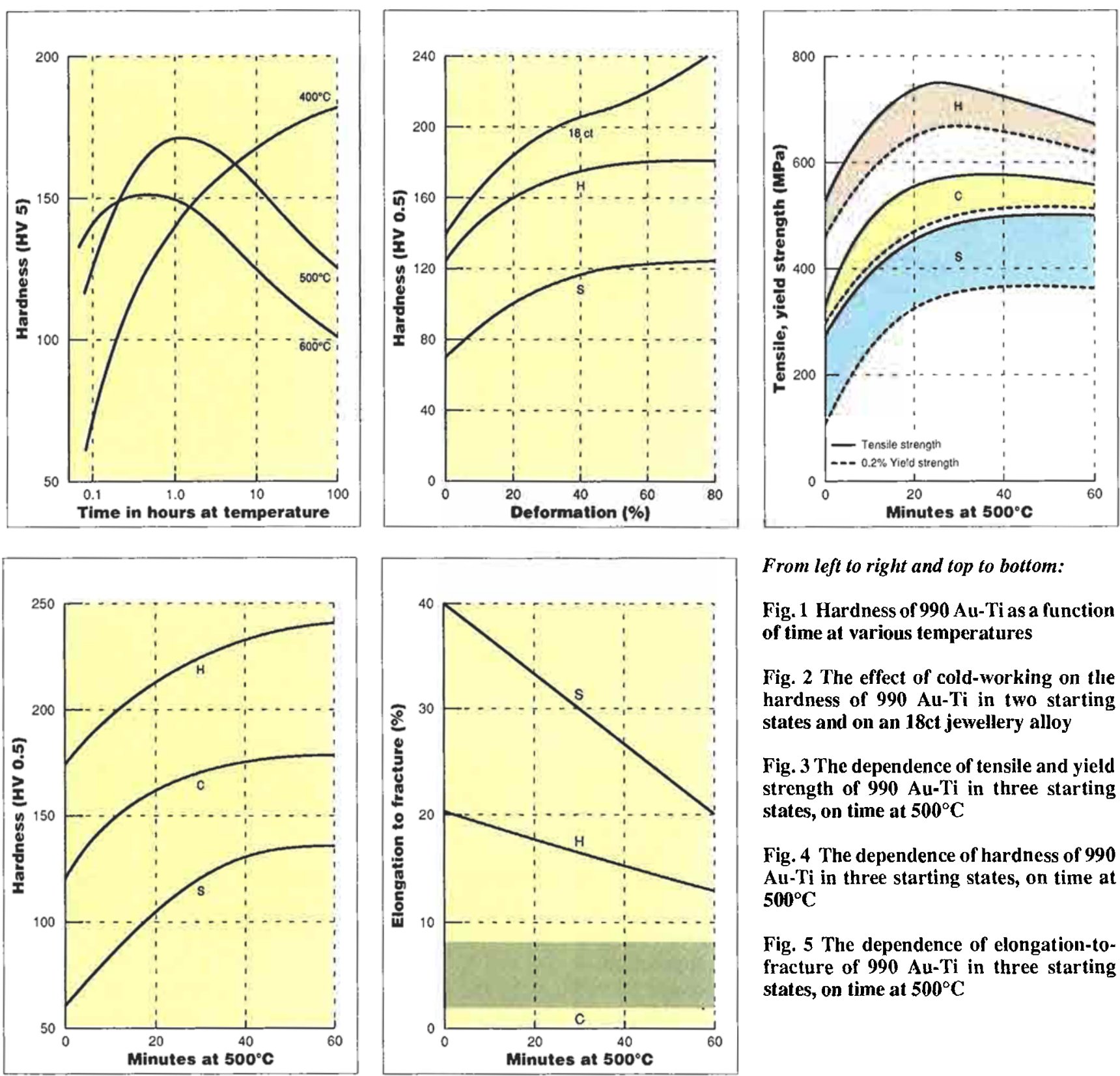

From left to right and top to bottom:

Fig. 1 Hardness of $990 \mathrm{Au}-\mathrm{Ti}$ as a function of time at various temperatures

Fig. 2 The effect of cold-working on the hardness of $990 \mathrm{Au}-\mathrm{Ti}$ in two starting states and on an 18ct jewellery alloy

Fig. 3 The dependence of tensile and yield strength of $990 \mathrm{Au}-\mathrm{Ti}$ in three starting states, on time at $500^{\circ} \mathrm{C}$

Fig. 4 The dependence of hardness of 990 Au-Ti in three starting states, on time at $500^{\circ} \mathrm{C}$

Fig. 5 The dependence of elongation-tofracture of $990 \mathrm{Au}-\mathrm{Ti}$ in three starting states, on time at $500^{\circ} \mathrm{C}$

Figure 4 illustrates the dependence of hardness and Figure 5 that of the percentage elongation to fracture, in the three starting states on time of hardening at $500^{\circ} \mathrm{C}$. Note the substantial variation of 2 to 8 per cent in the elongation-to-fracture values for cold-worked material. The reason for this is not understood as yet.

\section{Comparison of the properties of 990 gold with those of some other jewellery alloys}

Table II (p. 115) allows comparison of the colours, compositions, hardnesses, yield- and tensile-strengths and percentage elongations to fracture of some standard $14[15,16]$ and 18 carat alloys [17-20], pure gold [21] and 990 gold-titanium in three starting states [14], annealed (S), cold-worked (C) and hardened $(\mathrm{H})$. Where available, values are listed for each of these 13 starting 
Table III

\section{The Effect of Temperature and the Surrounding Medium on the Appearance, Shape and Purity of 990 Gold}

\begin{tabular}{|c|c|c|c|c|c|c|}
\hline Medium & $\underset{{ }^{\circ} \mathrm{C}}{\text { Temp. }}$ & $\begin{array}{l}\text { Time } \\
\text { min. }\end{array}$ & Appearance & Shape & Assay & Comments \\
\hline $\begin{array}{l}\mathrm{B}_{2} \mathrm{O}_{3} \\
540 \\
560 \\
\text { air }\end{array}$ & $\begin{array}{l}1150 \\
1150 \\
1150 \\
1150\end{array}$ & $\begin{array}{l}20 \\
20 \\
20 \\
20\end{array}$ & $\begin{array}{l}\text { Severely blackened } \\
\text { Grey, rough } \\
\text { Clean gold bead } \\
\text { Black/grey }\end{array}$ & $\begin{array}{l}\text { Unchanged } \\
\text { Disfigured } \\
\text { Melted to bead } \\
\text { Unchanged }\end{array}$ & $\begin{array}{l}999.5 \\
990.2 \\
999.8 \\
990.3\end{array}$ & $\begin{array}{l}\text { Almost all titanium reacted } \\
\text { Protective film formed } \\
\text { Almost all titanium reacted } \\
\text { Protective film formed }\end{array}$ \\
\hline $\begin{array}{l}\mathrm{B}_{2} \mathrm{O}_{3} \\
540 \\
560 \\
\text { air }\end{array}$ & $\begin{array}{l}800 \\
800 \\
800 \\
800\end{array}$ & $\begin{array}{l}60 \\
60 \\
60 \\
60\end{array}$ & $\begin{array}{l}\text { Bright gold } \\
\text { Bright gold } \\
\text { Bright gold } \\
\text { Brown }\end{array}$ & $\begin{array}{l}\text { Unchanged } \\
\text { Unchanged } \\
\text { Unchanged } \\
\text { Unchanged }\end{array}$ & $\begin{array}{l}989.3 \\
989.1 \\
987.8 \\
989.2\end{array}$ & $\begin{array}{l}\text { No reaction } \\
\text { No reaction } \\
\text { Reaction products remained in sample } \\
\text { No reaction }\end{array}$ \\
\hline $\begin{array}{l}140 \\
250 \\
430 \\
\text { Flux-h } \\
\text { air }\end{array}$ & $\begin{array}{l}500 \\
500 \\
500 \\
500 \\
500\end{array}$ & $\begin{array}{l}200 \\
200 \\
200 \\
200 \\
200\end{array}$ & $\begin{array}{l}\text { Darkened } \\
\text { Darkened } \\
\text { Bright gold } \\
\text { Bright gold } \\
\text { Darkened }\end{array}$ & $\begin{array}{l}\text { Unchanged } \\
\text { Unchanged } \\
\text { Unchanged } \\
\text { Unchanged } \\
\text { Unchanged }\end{array}$ & $\begin{array}{l}989.1 \\
989.0 \\
988.8 \\
989.1 \\
989.1\end{array}$ & $\begin{array}{l}\text { Surface film formed } \\
\text { Surface film formed } \\
\text { No reaction, salt not properly molten } \\
\text { No reaction } \\
\text { Surface film formed }\end{array}$ \\
\hline
\end{tabular}

materials after annealing (S), cold-working (C) and hardening $(\mathrm{H})$.

It will be seen that $990 \mathrm{Au}-\mathrm{Ti}$ has a low hardness $(70 \mathrm{HV})$ in the solutionized state and that this increases to $120 \mathrm{HV}$ on cold working. This is an ideal value for blanks which are to be coined. Coins and medallions can thus be produced in 990 without any annealing step between strip rolling-and-blanking and striking. Of all the other materials listed, only pure gold shares this property.

Ductility in both the solutionized state and after hardening is high, which results in easy coining and workability.

Heating for one hour at $500^{\circ} \mathrm{C}$ causes the hardness of such wrought pieces to rise to $210 \mathrm{HV}$.

Further hardening of 990 alloy in the $\mathrm{H}$ state at $500^{\circ} \mathrm{C}$ for one hour gives a hardness of $240 \mathrm{HV}$ and a tensile strength of $740 \mathrm{MPa}$, which compare acceptably with all other alloys listed except those hardened by high concentrations of copper. This material is suited to lathe turning using diamond tools for ring and bangle production.

The picture that emerges is thus one of a versatile alloy which can be treated to give material which can be used for the manufacture of both coin and wrought or turned jewellery.

\section{Effects of various salts and fluxes on the composition of 990 gold-titanium alloy during heat-treatment}

A study was undertaken with a view to establishing whether fluxes or salts could be used to shield the alloy from the atmosphere during production or heat-treatment, thus avoiding the use of vacuum equipment. The alloy used in the tests was in the form of a strip cut from a batch produced by vacuum methods. Analyses were carried out in the assay department of Rand Refinery.

Samples were cut from various points along the alloy strip and assayed to establish its gold content and uniformity. Results obtained ranged from millesimal finenesses of 989.15 to 989.40 with an average of 989.29 and a standard deviation of 0.08 . In what follows the fineness will be taken as $989.3+0.1$.

Heat treatments of alloy samples were made at 1150 and $800^{\circ} \mathrm{C}$ in $\mathrm{B}_{2} \mathrm{O}_{3}$, Degussa salt 540 , Degussa salt 560 , and air. Degussa salts 140,250 and 430 and Flux-t were used for the treatment at $500^{\circ} \mathrm{C}$ as those used at 800 and $1150^{\circ} \mathrm{C}$ did not melt at this lower temperature. Samples were assayed after manual removal of surface contamination. The results are summarized in Table III.

None of the salts or fluxes used was found to be inert with respect to the alloy at $1150^{\circ} \mathrm{C}$. The Degussa 560 


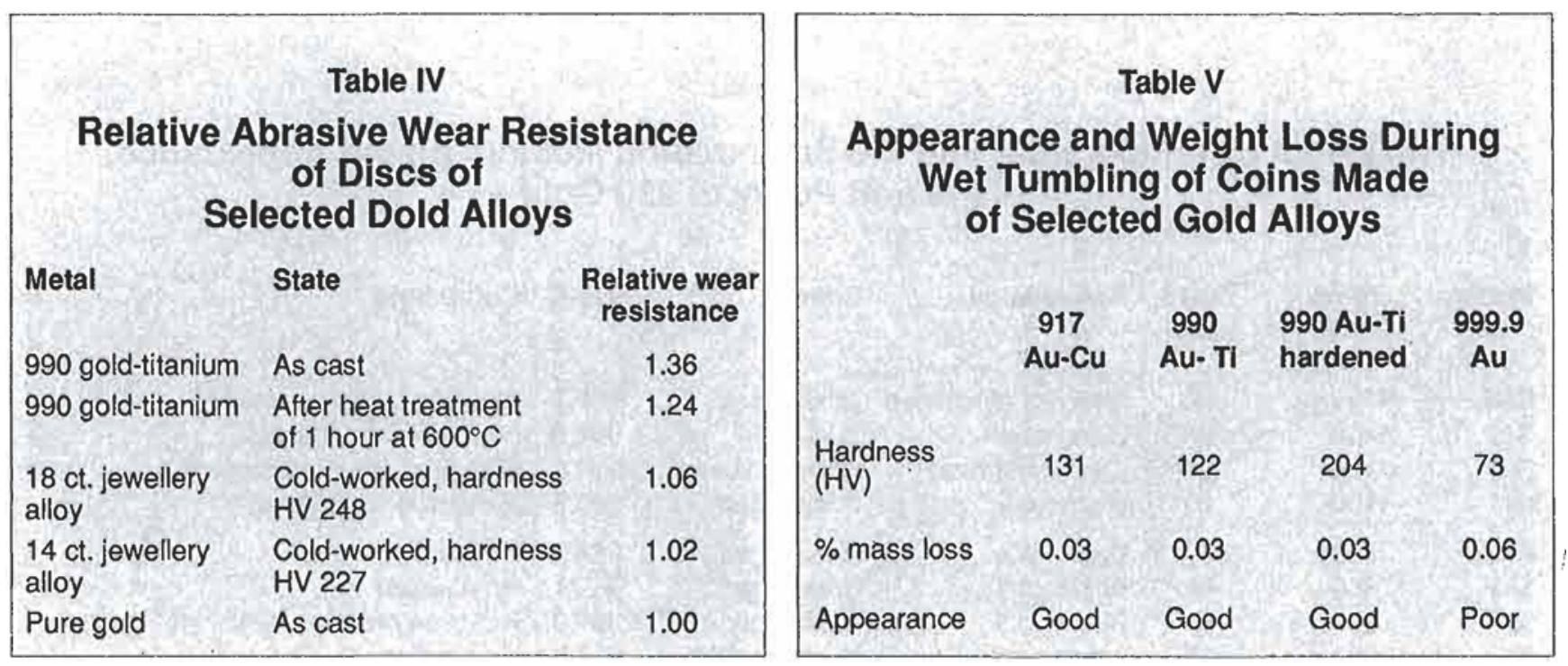

Table VI

\section{Relative Abrasive Wear Resistance of Samples from Coins Made of Selected Gold Alloys}

\begin{tabular}{|c|c|c|c|}
\hline nulinglimb2003 & 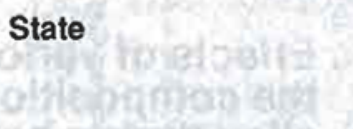 & $\begin{array}{l}\text { Hardness } \\
\quad \mathrm{HV}_{5}\end{array}$ & $\begin{array}{l}\text { Relative wear resist- } \\
\text { ance at steady state }\end{array}$ \\
\hline Pure gold & As-cast and coined & 77 & 1.00 \\
\hline $\begin{array}{l}18 \mathrm{ct} \text {. alloy } \\
750 \mathrm{Au}-150 \mathrm{Ag}-100 \mathrm{Cu}\end{array}$ & Cold worked and coined & 234 & 0.83 \\
\hline $917 \mathrm{Au}-\mathrm{Cu}$ & Annealed and coined & 113 & 1.04 \\
\hline $990 \mathrm{Au}-\mathrm{Ti}$ & $\begin{array}{l}\text { Solutionized, } 50 \% \\
\text { cold worked and coined }\end{array}$ & 132 & 1.25 \\
\hline-715 y sethe & $\begin{array}{l}\text { Solutionized, } 50 \% \\
\text { cold worked, coined } \\
\text { and age hardened }\end{array}$ & 185 & $\begin{array}{l}1.10 \\
\end{array}$ \\
\hline
\end{tabular}

salt is so reactive that it provides a simple medium for refining 990 gold-titanium alloy scrap.

Only the Degussa 560 salt showed evidence of reaction with the alloy at $800^{\circ} \mathrm{C}$ and the 0.16 per cent decrease in gold content must be due to reacted titanium staying in or on the sample notwithstanding manual cleaning (this result was confirmed on repetition).

The alloy can be homogenized readily at $800^{\circ} \mathrm{C}$ in $\mathrm{B}_{2} \mathrm{O}_{3}$ or Degussa 540 salt. Of these, the latter is preferred as it is free of the high viscosity and glass-like properties of $\mathrm{B}_{2} \mathrm{O}_{3}$.

Only salt 430 and Flux-h were found to be acceptable when heat treating the alloy at $500^{\circ} \mathrm{C}$. Of these, Flux-h is recommended as salt 430 does not melt completely at $500^{\circ} \mathrm{C}$.

In summary thus, Degussa salt 560 can be used to remove titanium from molten 990 scrap. Solutionizing can be carried out effectively under Degussa salt 540 and heat-treatment at $500^{\circ} \mathrm{C}$ under Degussa Flux-h. 


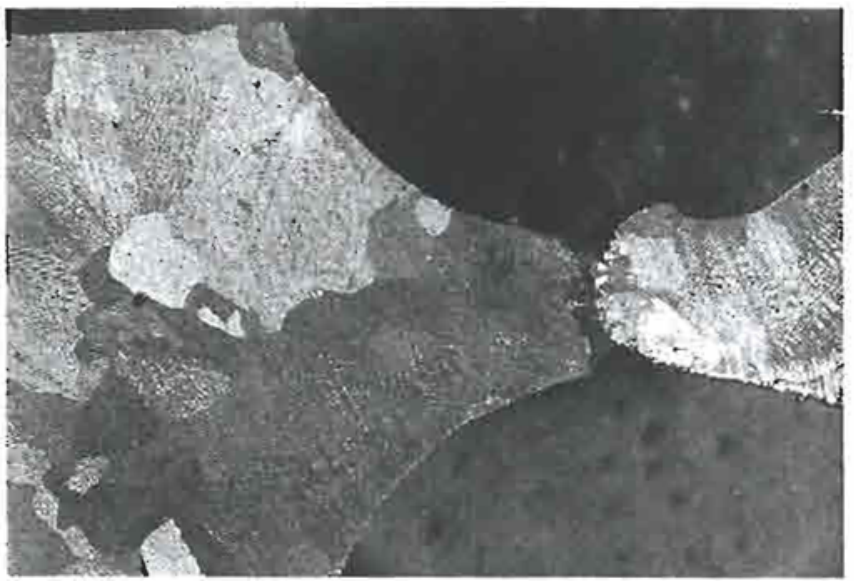

Fig. 6a The texture of cast $990 \mathrm{Au}-\mathrm{Ti}$ (x6.5)

The utilization of vacuum equipment for alloy production remains a necessity.

\section{Wear resistance}

Two tests were carried out by Degussa using the method described by Heidsiek and Clasing [22]. This involves measuring weight loss after drawing discs of the test samples over cloth which has been impregnated with abrasive particles. Designating the wear resistance of pure gold as unity, Table IV (p. 118)gives the relative wear resistances of the materials tested [23].

Tests were also performed on the damage to and weight loss of coins on tumbling for 24 hours in soapy water in the presence of $3 \mathrm{~mm}$ ball bearings and $4 \mathrm{~mm}$ rods cut from $3 \mathrm{~mm}$ stainless steel wire. Results obtained are given in Table V (p. 118).

Notwithstanding their higher purity, $990 \mathrm{Au}-\mathrm{Ti}$ coins have the same weight loss (wear resistance) on tumbling as the standard 917 Au-Cu coinage alloy. They also retain the detail of their features as well as does the coinage alloy. The 999.9 gold coins lose weight twice as fast as the others and become defaced readily.

Abrasive wear tests were also carried out on discs punched from coins [24], again using the method of Heidsiek and Clasing [22]. The results are given in Table VI (p. 118).

As before, the 990 coins show substantially better wear resistance than the other three types tested.

Wear tests have been carried out on three 990 rings. One was worn on the same finger as a 14 ct. ring and found to wear at an annual rate of 1.2 weight per cent. The $14 \mathrm{ct}$. ring wore slightly faster at 1.4 weight per cent [25].

The other two rings were worn out of contact with other jewellery and found to lose material annually at

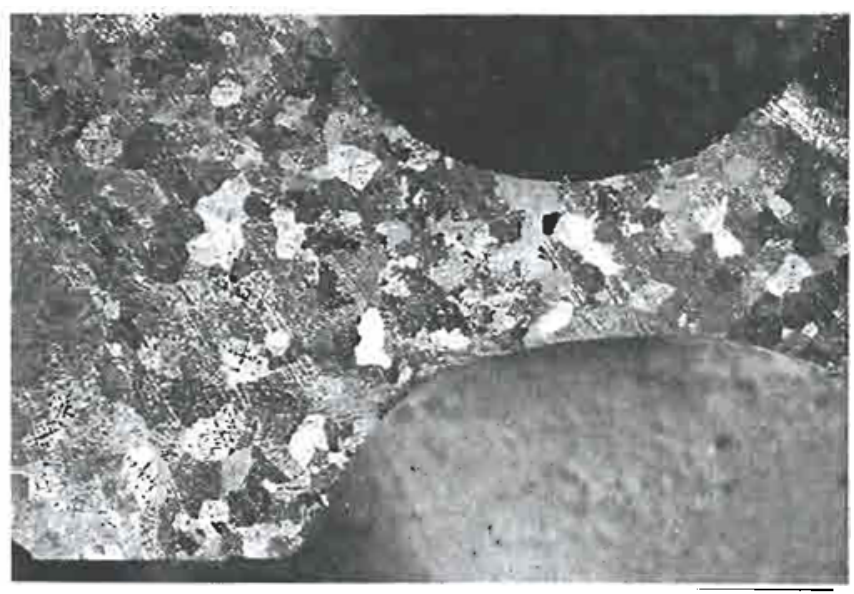

Fig. 6b The texture of cast $990 \mathrm{Au}, 9.1 \mathrm{Ti}, 0.5 \mathrm{Ru}, 0.4 \mathrm{~B}$ indicating grain refinement $(\mathbf{x} 6.5)$

\section{4 per cent.}

Wear tests on 9 and $18 \mathrm{ct}$ rings carried out by the Worshipful Company of Goldsmiths for Intergold [26] gave annual weight losses varying from 0.3 to 2.3 per cent with results being dependent on the wearer rather than the type of ring.

These limited tests indicate that 990 rings undergo at worst comparable, and probably less wear than other rings.

In summary thus the wear properties of 990 coins and rings are good when compared with similar objects made of other standard alloys.

\section{Refining of scrap}

Due to the oxide/nitride skin which forms on heating $990 \mathrm{Au}-\mathrm{Ti}$, it is not possible to recycle scrap by simply melting it. It has, however, been established that the titanium can readily be removed by melting scrap under Degussa precious metal salt 640 . This refines the alloy to 999.8 fineness gold in 20 minutes at $1100^{\circ} \mathrm{C}$. This purified gold can be vacuum melted with titanium to yield further 990 alloy.

The presence of one percent of titanium in scrap does not complicate its normal refining by the Miller process. This is, however, seldom an in-house procedure which is available to producing jewellers.

\section{Soldering and welding}

Soldering 990 presents no particular problems. Surfaces to be soldered must be thoroughly cleaned of all contaminants by sandpapering or filing if necessary. The whole surface which is to be heated must be covered with flux to prevent tarnishing. Suitable fluxes are Degussa-Flux $t$ or $-\mathrm{h}$, or Canning. There is reason to believe that other high quality jewellers' fluxes will 


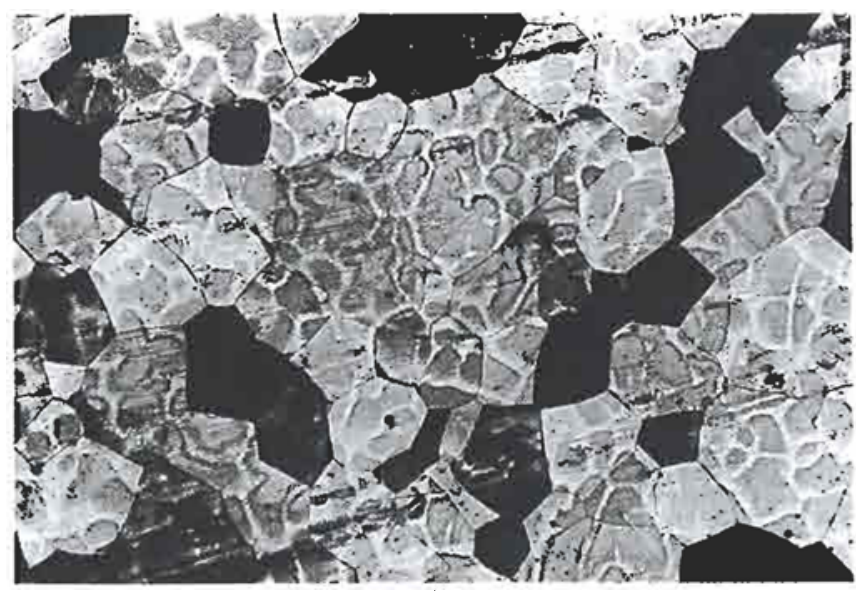

Fig 7a The texture of as-cast $990 \mathrm{Au}-\mathrm{Ti}$ (x130)

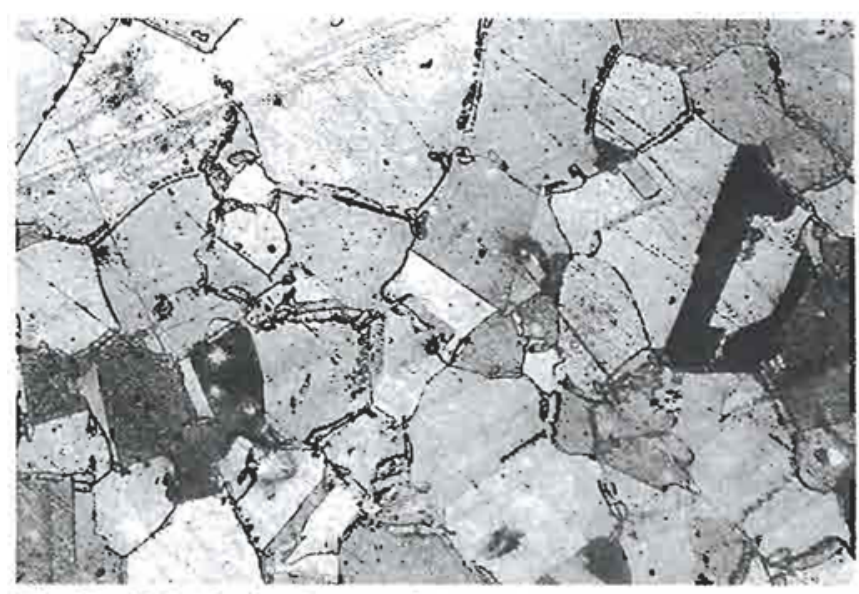

Fig. 7c Solutionized material age-hardened at $500^{\circ} \mathrm{C}$ for 1 hour (x130)

work equally well. Standard 22 ct. brazes are effective and can be matched to the colour of 990 .

Welding also presents no problems other than tarnishing of heated areas if these are not covered with flux. Some loss of titanium from the molten areas accompanies welding. Soldering is thus the preferred method for joining pieces as the amount of solder can be kept very small.

\section{Grain refinement}

A dramatic improvement in as-cast grain size is obtained when the alloy has the following composition [27]:

Au 990; Ti 9.1; Ru 0.5; B 0.4.

Texture differences between $990 \mathrm{Au}-\mathrm{Ti}$ and this alloy are shown in Figures $6 a$ and $6 \mathrm{~b}$ respectively.

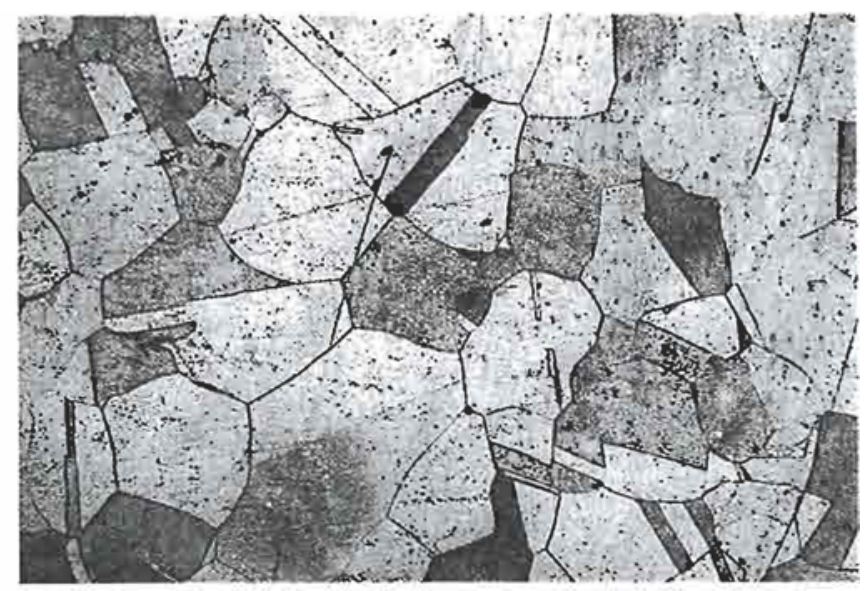

Fig $7 \mathrm{~b}$ After $70 \%$ cold-work followed by solutionizing at $800^{\circ} \mathrm{C}$ for 1 hour $(\mathrm{x130})$

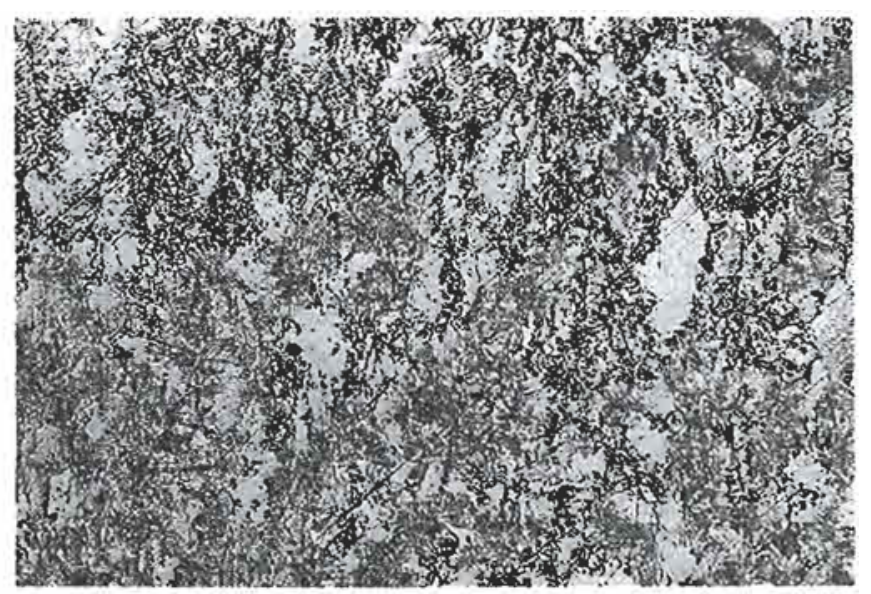

Fig. 7d Grain refinement following age-hardening of $70 \%$ deformed material for 1 hour at $500^{\circ} \mathrm{C}(\mathrm{x130})$

Large changes in texture also occur when the 990 Au-Ti alloy is deformed and hardened [14]. Examples of the texture of the alloy in various states is shown in Figure 7. The coarse 'as-cast' structure is shown in 7a. The texture of material which has been 70 per cent cold-worked and then solutionized is shown in 7b. Agehardening at $500^{\circ} \mathrm{C}$ for one hour of solutionized material leads to grain boundary segregation, $7 \mathrm{c}$. The dramatic grain refining effect of age hardening 70 per cent deformed material for one hour at $500^{\circ} \mathrm{C}$ is shown in Figure 7d.

\section{Casting}

$990 \mathrm{Au}-\mathrm{Ti}$ can be cast in pure argon at a pressure of $200 \mathrm{mbar}$ before and $700 \mathrm{mbar}$ after casting [28]. The 
investment material must be phosphate bonded. The crucible used in the test was graphite, melt temperature $1350^{\circ} \mathrm{C}$, casting temperature $1200^{\circ} \mathrm{C}$ and flask temperature $600^{\circ} \mathrm{C}$. Replacing some of the titanium by ruthenium/boron as described under 'grain refinement' above gives improved and acceptable grain size in the cast pieces.

It must be stressed that a limited number of casting tests have been carried out and that 990 cannot be classed as a casting alloy at this stage of its development. As the alloy is more amenable to the production of wrought jewellery this aspect has received far more attention.

\section{Patent application}

With a view to ensuring the quality of 990 semi-products being offered to the trade by licensing only to modern firms acquainted with vacuum technology, a patent application was made in West Germany (P35 02 914.5) by Intergold with the author as inventor [29]. This followed a search by the Patent Information Office in Holland which indicated no prior art which seemed likely to invalidate an application concerning the use of the alloy for jewellery manufacture. Graham [30] had, however, noted that titanium could be used for precipitation hardening gold in his dislocation study of the system.

This application was followed by the filing of applications in the USA, Europe, Japan and various other important regions. Criticisms received of the application included one of 1912 vintage from the U.S. Patent Office [31], which covers the hardening of gold-copper alloys by using titanium as a scavenger which slags off to leave a purer alloy. Notwithstanding this, the following paragraph is included in the body of the text: 'It will be understood that where the presence of some titanium per se may be unobjectionable, as for uses other than coinage, the titanium introduced may be so proportioned as to leave in the final product a decided percentage of titanium say up to one per cent or thereabouts, whereby in some instances greater resistance to abrasion may be imparted than when the titanium has been proportioned to leave only traces, or substantially no titanium in the final product. It will be understood that the claimed invention is limited to methods of treatment of gold, or its alloys,...'

Although this does not form part of any of the claims, it clearly negates the patent application by Intergold and this was therefore dropped.

\section{Summary and conclusions}

The alloy designated ' 990 ' comprising one per cent by weight of titanium in gold ( 990 millesimal fineness) has been found to have colour, mechanical properties and resistance to wear which make it eminently suitable for the production of wrought jewellery, coins and medallions.

Production of the alloy must be in a vacuum, backfilled to at least one torr with argon. All other procedures can be carried out with the usual goldsmith's facilities and do not require recourse to vacuum equipment or protective atmospheres.

Ductility is high and cold-working of 990 gives a maximum hardness of $125 \mathrm{HV}$ - an ideal value for coin blanking and stamping, wire drawing and wrought jewellery production. Solutionizing occurs at $800^{\circ} \mathrm{C}$ in a salt bath without loss of titanium and, following quenching, gives soft metal with a hardness of $75 \mathrm{HV}$. Age-hardening of this material occurs after one hour at $500^{\circ} \mathrm{C}$ and flux can be used to avoid tarnishing. Age hardening of cold-worked 990 gives hardnesses of up to $240 \mathrm{HV}$, which makes it ideal for turning with diamond tools during ring and bangle production. The alloy's other mechanical properties are comparable with those of the best jewellery and coinage alloys.

The durability of 990 has been shown to be better than that of all other standard coinage and jewellery alloys against which it was tested.

Scrap can be purified by melting in a suitable salt and soldering presents no problems if sufficient flux is used.

990 gold is the only significantly different jewellery and coinage alloy developed recently and holds promise for opening up a new segment at the top of the jewellery market.

As patent coverage could not be obtained, the alloy is available for all to use.

\section{Synopsis}

The paper gives the reasons for developing a 990 fineness gold alloy with good colour, durability and mechanical properties, and explains why titanium was chosen as the alloying metal.

Methods are described for the alloy's production, solutionizing and age-hardening. Mechanical properties are given as a function of deformation, age-hardening time and temperature for three different starting states. These properties are compared with those of some standard 14 and $18 \mathrm{ct}$ jewellery alloys and pure gold. 
The effects of various salts and fluxes on the composition of the alloy after heat treatment at 1150,800 and $500^{\circ} \mathrm{C}$ are given. These indicate how alloy scrap can be refined to pure gold, and how solutionizing and agehardening can be performed without recourse to vacuum equipment.

Results of wear tests are given which indicate that the alloy is more durable than normal coinage and jewellery alloys. Tips are given on grain refining, soldering and casting the alloy.

\section{Acknowledgements}

Acknowledgement is gratefully made to the following persons:

Dr Ch.J. Raub and D. Ott of the Forschungsinstitut für Edelmetalle und Metallchemie, Schwäbisch Gmünd, Federal Republic of Germany, for carrying out most of the sponsored research and incorporating many of their own ideas into it.

Dr Keller-Bauer and Mrs R. Hirzel of the firm of Christian Bauer in Welzhein, Federal Republic of Germany, for sanctioning and arranging the 990 ring and bangle production trials.

Mr C.J. Dannhauser of the S.A. Mint, for sanctioning coinage trials and $\mathbf{J}$. Roux for carrying them out

Dr W.S. Rapson, Consultant to Intergold, for his continuing interest in, and advice, on the project.

Dr O.A. Kunze, Intergold's Information Manager, for arranging the patent search and providing relevant information as required.

Drs H-H. Beyer, J. Hausselt and U. Mürrle of Degussa A.G., Wolfgang, Federal Republic of Germany, for their collaboration in a variety of aspects relating to the study and, in particular, the wear tests and production trials.

Messrs. C. Knoesen and A.W. George of the Rand Refinery Ltd., for carrying out the analyses reported in Table III.

\section{References}

1 Engelhard Industries, U.S. Patents 2947114 (1960), 2984894 (1961), 3049577 (1962), 3201236 (1965), 3606766 (1971)

2 M.L. Gimpel and N. Fuschillo, J. Met., 1971, 33(6), 39

3 N. Fuschillo and M.L. Gimpel, J. Mater: Sci., 1970 , 5(12), 1078

4 M. Poniatowski and M. Clasing, Gold Bull., 1972, 5(2), 14

5 J.S. Hill, Gold Bull., 1976, 9(3), 76-80

6 H-H. Beyer, M. Clasing \& H. Heidsiek, Report by Degussa on research co-sponsored by the International Gold Corporation Ltd., August, 1982
7 Degussa AG, German Patent DE 040981 (1983)

$8 \mathrm{H}$. Heidsiek, V. Naumann \& G Ondracek, 11 th Int. Plansee Seminar, 1985, 1, 575-585 and Int. J. of Powder Metallurgy, 1986, 22, 113-117

9 Private Communication, J. Lai, 1983

10 H. Okamoto and T.B. Massalski, Preprint of: ASM/NBS Monographs Series on Binary Phase Diagram Evaluations, Nos. 1 and 2, Gold-Based Binary Alloy Phase Diagrams

11 Ch. J. Raub \& D. Ott, Sponsored Research Report by the Forschungsinstitut für Edelmetalle und Metallchemie (FEM) to the International Gold Corporation Ltd., May, 1984

12 Ch.J. Raub, Consultancy Report by the FEM to the International Gold Corporation Ltd., September, 1986

13 K.B. Guy \& G.Humpston, Report on research co-sponsored by General Electric Research Ltd. (Hirst Research Centre) and the International Gold Corporation Ltd., November 1986

14 Ch.J. Raub \& D.Ott, Sponsored Research Report by the FEM to the International Gold Corporation Lid., May, 1985

15 Gold Alloy Data, Aurum No. 14, 1983, 141-44

16 P. Ramoni, Aurum No. 6, 1981, 23-29

17 Gold Alloy Data, Aurum No. 1, 1980, 22-25

18 Gold Alloy Data, Aurum No. 2, 1980, 15-18

19 Gold Alloy Data, Aurum No. 3, 1980, 15-18

20 Gold Alloy Data, Aurum No. 5, 1981, 20-23

21 Duduco Data Book, 2nd Edition, October, 1983, p58

22 H. Heidsiek and M. Clasing, Gold Bull., 1983, 16, 76-81

23 J. Hausselt and U. Muirrle, Test Report to the FEM, May, 1985

24 J. Hausselt and U. Mürrle, Test Report to the International GoId Corporation Ltd., November, 1986

25 Ch.J. Raub and H. Weiss, Consultancy Report by the FEM to the International Gold Corporation Ltd., August, 1985

26 B. Taylor, Aurum No. 6, 1981, 46-50

27 Ch.J. Raub and D. Ott, Sponsored Research Report by the FEM to the International Gold Corporation Ltd., September, 1986

28 Ch.J. Raub and D. Ott, Sponsored Research Report by the FEM to the International Gold Corporation Lrd., December, 1985

29 G. Gafner, International Gold Corporation Ltd., Federal Republic of Germany Patent P35 02 914.5, 1985

30 M. Graham, 31 st Annual EMSA Meeting, 1980, 148-9

3 I A.J. Rossi, Titanium Alloy Manufacturing Co. of New York, U.S. Patent 1023334, 1912 